\title{
Detection and description of a particular Ostreid herpesvirus 1 genotype associated with massive mortality outbreaks of Pacific oysters, Crassostrea gigas, in France in 2008
}

\author{
Amélie Segarra $^{\mathrm{a}}$, Jean François Pépin ${ }^{\mathrm{a},{ }^{*}}$, Isabelle Arzul ${ }^{\mathrm{a}}$, Benjamin Morga ${ }^{\mathrm{a}}$, Nicole Faury ${ }^{\mathrm{a}}$ and Tristan \\ Renault ${ }^{\mathrm{a}}$ \\ a Institut Français de Recherche pour l'Exploitation de la Mer (IFREMER), Laboratoire de Génétique et \\ Pathologie (LGP), Avenue de Mus de Loup, 17390 La Tremblade, France \\ *: Corresponding author : Jean François Pépin, Tel.: +33 5467626 48; fax: +33 5467626 11, email address : \\ ifpepin@ifremer.fr
}

\begin{abstract}
:
Ostreid herpesvirus 1 (OsHV-1) infections have been reported around the world and are associated with high mortalities of the Pacific oyster (Crassostrea gigas). In the summer 2008, abnormal mortality rates ranging from $80 \%$ to $100 \%$ were reported in France and affected only Pacific oysters. Analyses of oyster samples collected during mortality outbreaks demonstrated a significant detection of OsHV-1 (75\% of analysed batches), which appeared stronger than previous years. DNA sequencing based on $\mathrm{C}$ and IA regions was carried out on 28 batches of OsHV-1 infected Pacific oysters collected in 2008. Polymorphisms were described in both the $\mathrm{C}$ and IA regions and characterized a genotype of OsHV-1 not already reported and termed OsHV-1 $\mu$ Var. A microsatellite zone present in the $C$ region showed several deletions. Additionally, 44 isolates collected in France and in the USA, from 1995 to 2007 were sequenced and compared to the 2008 sequences. The analyses of 76 sequences showed OsHV-1 $\mu \mathrm{Var}$ detection only in 2008 isolates. These data suggest that OsHV-1 $\mu \mathrm{Var}$ can be assumed as an emergent genotype.
\end{abstract}

Keywords: Herpes virus; Oyster; Crassostrea gigas; OsHV-1 $\mu$ Var; Increased mortality; Microsatellites 


\section{Introduction}

Since 1993 high mortalities of spat and juveniles of Crassostrea gigas (Thunberg) are regularly observed in batches of Pacific oyster cultured in different French locations occurring each year during summer period in association with a herpes-like virus (Renault et al., 1994; Renault et al., 2000a, 2000b). A similar virus was also reported in the USA during mortality outbreaks (Burge et al. 2006, Burge et al., 2007). Despite these findings, the aetiology of summer mortalities seems to be multifactorial, arising as a result of complex interactions between the physiological status of the host, the environment and pathogens such as bacteria of the genus Vibrio and/or a herpes virus (Samain and McCombie, 2008, Sauvage et al., 2009).

The repeated mortalities associated with herpesviruses in bivalves, particularly in C. gigas, and the economic importance of $C$. gigas as an aquaculture product lead to sequencing and characterization of the Ostreid herpesvirus 1 (OsHV-1) (Davison et al. 2005) in the Family Herpesviridae. Recently, OsHV-1 was included in the re-classification of the Order Herpesvirales as the lone member of the Family Malacoherpesviridae (Davison et al. 2009). Molecular tools based on OsHV-1, including conventional Polymerase Chain Reaction (CPCR), in situ hybridization, and quantitative PCR have been developed to study OsHV-1 infections (Renault and Lipart, 1998; Renault et al., 2000b; Arzul et al., 2002; Lipart and Renault, 2002; Pépin et al., 2008). These tools allow rapid identification and/or confirmation of OsHV-1 in animals presenting unusual mortalities. CPCR followed by sequencing of PCR products also allowed the description of possible OsHV-1 variants (Arzul et al., 2001a; Friedman et al., 2005; Moss et al., 2007). A variant, named OsHV-1var (Arzul et al., 2001a) was associated with mortalities of bivalves including Ruditapes phillipinarum (Arzul et al., 2001a), Crassostrea gigas and Pecten maximus (Arzul et al., 2001b) in French hatcheries. Although the variant genotype presents several modifications in the $C$ region and more importantly, a $2.8 \mathrm{kpb}$ deletion, OsHV-1 and OsHV-1var are considered representative of a single viral species (Arzul et al., 2001a).

In the summer of 2008 , widespread mortalities were reported in French stocks of $C$. gigas grown in all production areas and killed billions young oysters. Outbreaks were first observed in April/May. Mortality outbreaks were usually sudden and affected principally spat (oysters less than 1-year old) and juveniles (12-18-month-old oysters). Mortality rates of 40 to 100\% were experienced. The Pacific oyster appears to be the only shellfish species affected by these mortalities. Samples were collected from all affected locations and tested in order to search pathogens. Different diagnostic tests were carried out and results indicated that (1) there was no officially notifiable pathogen involved, (2) OsHV-1 was detected in most of samples especially in moribund oysters, (3) $V$ splendidus, $V$. aestuarianus and Vibrio. harveyi were also detected in affected oysters and (4) viral particles looking like herpes viruses were observed by TEM in moribund tested oysters. Among batches affected by mortality and analysed for pathogens detection $75 \%$ were positive for OsHV-1. (Anon., 2008; Pernet et al., 2010). Because of the exceptional mortality level associated with an abnormally high frequency of detection of OsHV-1 in all livestocks, the average detection rate increased by at least 30\% according to data monitoring from 1997 - 2005 (Celine Garcia, personal communication), a increased need has emerged to better characterize isolates of herpes viruses found in infected batches.

Investigations were conducted in order to identify additional factors including emerging strains of known pathogens (i.e. emerging OsHV-1 genotype). The aim of the present study was to determine if OsHV-1 detected in C. gigas during the 2008 abnormal mortalities was similar to the characterized OsHV-1 reference genotype (GenBank accession number AY509253: virus isolate from Pacific oyster larvae in 1995). OsHV-1 detection was performed by PCR (Renault and Arzul, 2001) followed by restriction endonuclease digestion of PCR products and DNA sequencing in order to study virus polymorphism into ORF4 and ORF43. 


\section{Material and methods}

\subsection{Sample selection}

Twenty-eight batches representing thirty-two isolates of DNA extracted from C. gigas spat or juvenile oysters were selected among the samples collected by the French network for surveillance of mollusc diseases (Repamo, Ifremer) during 2008 mortality events (Table 1).

Batches were selected for analysis based on high mortality rates $(>70 \%)$ and their geographic origins (Normandy, north Brittany, south Brittany, Vendée, Charente-Maritime, Arcachon and Thau lagoon). Selected batches were also representative of type practices, hatchery produced or wild captured spat oysters. In addition, analyses were also performed retrospectively on archived samples collected between 1995 and 2007 in France and in the USA (Table 2). These 44 isolates were selected not because of their locations but because they were associated with mortality events in oysters that occurred before the French mass mortality from 2008. The aim of testing this samples old collection was to look for the potential occurrence of the newly described genotype OsHV-1 $\mu$ Var herein.

Nucleic acid extraction. Samples from oysters were processed for nucleic acid extraction using the QIAamp DNA Mini Kit (Qiagen) according to the manufacturer's protocol.

\subsection{PCR conditions}

OsHV-1 specific PCR analyses were performed using three primer pairs targeting two different regions of the OsHV-1 genome: IA (ORF43) and C (ORF4). Region IA encodes a putative apoptosis inhibitor (I. Arzul, unpublished data ) and region $C$ encodes two proteins of unknown function (Renault and Arzul, 2001). The first primer pair was designed from herpes viral sequences (Davison et al. 2005; I. Arzul, unpublished data), IA1/IA2 amplified a 607 bp fragment (Table 3). The second primer pair, C2/C6 amplified a 709 bp fragment (Renault and Arzul, 2001) (Table 3). The primers were synthesized and supplied by Eurogentec (Belgium). PCR analysis was carried out as prev

iously described (Renault and Arzul, 2001) Briefly, one round PCR was carried out in a final reaction volume of $50 \mu \mathrm{l}$. Each reaction volume contained $2.5 \mathrm{U}$ of Taq Goldstar Polymerase (Eurogentec, Belgium), 10x reaction buffer (Eurogentec, Belgium), $2.5 \mathrm{mM} \mathrm{MgCl}, 0.05 \mathrm{mM}$ of each dNTP, $10 \mu \mathrm{M}$ of each primer. DNA was added under a volume of $1 \mu \mathrm{l}$. After heating DNA samples for 2 min at $94^{\circ} \mathrm{C}, 35$ cycles were carried out followed by a final elongation step of 5 min at $72^{\circ} \mathrm{C}$. Each of the 35 cycles consisted of a DNA melting step at $94^{\circ} \mathrm{C}$ for 1 min, a primer annealing step for $1 \mathrm{~min}$ at $50^{\circ} \mathrm{C}$ and a primer elongation step at $72^{\circ} \mathrm{C}$ for 1 min. Negative controls consisted of $1 \mu \mathrm{l}$ of distilled water. Two nanogram of genomic virus DNA extracted from purified particles (Le Deuff and Renault, 1999) was added as positive control. PCR products was size selected on $1.5 \%$ agarose gels, stained with ethidium bromide $(5 \mu \mathrm{l} / 100 \mathrm{ml})$ and visualized using a 302-nm UV transilluminator.

\subsection{Restriction fragment length polymorphism (RFLP) analysis}

The PCR products were digested with $10 \mathrm{U}$ of restriction endonucleases during 2 hours in a final reaction volume of $20 \mu \mathrm{l}$ at $37^{\circ} \mathrm{C}$ with Xhol and Styl on C2-C6 PCR products, at $37^{\circ} \mathrm{C}$ with $\mathrm{Mspl}$ and at $60^{\circ} \mathrm{C}$ with Taql on IA1-IA2 PCR products. Digested products were size selected on $2 \%$ agarose gels. Restriction maps of the reference digested PCR products when the C2/C6 and IA1/IA2 primer sets were used are shown in Table 4 (Arzul et al., 2001a; I. Arzul, unpublished data). Positive control consisted of purified viral DNA. Negative control was formed by distilled water. 


\subsection{PCR products purification}

PCR products were purified using Montage ${ }^{\circledR}$ Centrifugal Filter Devices according to the Millipore Kit. Fresh purified products were analysed on 1.5\% agarose gels with DNA ladder corresponding to the expected fragments. The picture of the gel was analysed with Quantity One Software in order to calculate the concentration of samples before sequencing.

\subsection{Direct nucleotide sequencing}

The sequencing reaction was carried out into a $10 \mu \mathrm{l}$ final volume, containing $1.8 \mu \mathrm{l}$ of sequencing buffer, $0.4 \mu \mathrm{l}$ of BigDye ${ }^{\circledR}$ Terminator v3.1 (Applied Biosystems), $1.5 \mu \mathrm{l}$ of primer Forward or Reverse at $4 \mu \mathrm{M}$ (primers are the same used for the classical one round PCR Table 3), fresh purified PCR products and DNAse and RNAse free sterile water qsp to $10 \mu \mathrm{l}$. The programme consisted in an initial denaturation of 3 minutes at $96^{\circ} \mathrm{C}$ followed by 35 cycles of $30 \mathrm{~s}$ at $96^{\circ} \mathrm{C}, 30 \mathrm{~s}$ at $50^{\circ} \mathrm{C}$ and 4 minutes at $60^{\circ} \mathrm{C}$. Reactions were performed using 96-well plates. Sequencing reactions were then purified as follows. In each sample, $60 \mu \mathrm{l}$ of $100 \%$ ethanol were added and samples were centrifuged at $3000 \times \mathrm{g}$ for 30 minutes. The plate was inverted to remove ethanol. Then, $60 \mu \mathrm{l} 70 \%$ ethanol were added, followed by centrifugation of plates at $1650 \times \mathrm{g}$ for 10 minutes. The plate was then centrifuged upside down for 30s to remove the ethanol. Finally, samples were dried in a Speed Vac and resuspended with $10 \mu \mathrm{l}$ formamide. Samples were loaded in ABI PRISM® 3130 XL-Avant Genetic Analyzer, using a $36 \mathrm{~cm}$ capillary array and POP 7 polymer.

\subsection{Sequence alignment}

Sequence base pairs were called with Chromas lite 2.01 version software. Multiple alignments were achieved by Bioedit 7.0.9 version software using the algorithm CLUSTAL W. Sequence results were compared to the consensus sequence OsHV-1 available on GENBANK (accession number AY509253). PCR products from all isolates of 2008 and previous years were sequenced twice on order to confirm results. Expected protein sequences were compared by translating the nucleotide sequences to amino acid sequences.

\section{Results}

\subsection{PCR}

A preliminary study was performed using PCR primers targeting different regions of the genome as Gp (ORF88), IA (ORF43) and C (ORF4) using four isolates. As a larger percentage of polymorphisms was observed using $C$ (ORF4) and IA (ORF43) than Gp (ORF88), the $C$ and IA regions were chosen for further PCR analyses. Twenty-eight batches of Pacific oysters collected in 2008 representing 6 geographic regions, were analysed by PCR using the primer pairs IA1/IA2 and C2/C6. PCR analysis with the IA1/IA2 and C2/C6 primers resulted in amplicons of expected size for the 28 batches, $607 \mathrm{bp}$ and $709 \mathrm{bp}$, respectively. After gel analysis no difference was observed between samples and positive controls (Fig. 1). No PCR product was detected in negative controls.

\subsection{RFLP analysis}


The IA1/IA2 and C2/C6 PCR products were digested using 4 restriction enzymes. IA products digested by Taql and Mspl displayed an equal restriction profiles for the 28 batches compared to the restriction profile of the reference OsHV-1 isolate (Fig. 2). Similar results were observed for C2/C6 PCR products digested by Xho1 and Sty1 (Fig. 3). Gel analysis displayed no difference between samples and positive reference controls.

\subsection{Sequence analysis}

The IA1/IA2 and C2/C6 PCR products were sequenced from 32 isolates in 2008. Using the C2/C6 primers, 17 isolates were identical to the OsHV-1 reference isolate, while 15 showed sequence variations. These 15 isolates were identical to each other. Polymorphisms included a single addition, several substitutions and deletions. (Fig. 4). The main deletion consisted of 12 consecutive nucleic acids in a repeated region of trinucleotides characterized by a "CTA" pattern, followed by one deletion of "one Adenine (A)". This microsatellite present in the reference OsHV-1 isolate is formed of $24 \mathrm{bp}$. This motif is located in the interval $4487-4510$ (nucleotide position in total genome) but also in the interval 178547-178570 because $\mathrm{C}$ region is a inverted repeat. The "CTA" pattern is repeated 4 times in these 15 isolates whereas it is repeated 8 times in the reference OsHV-1 isolate (Fig. 4). Two nonsynonymous substitutions were else reported in the coding zone of the $C$ region. The genotype of OsHV-1 presenting these modifications has been called OsHV-1 $\mu$ Var in order to differentiate it with already described genotypes OsHV-1 and OsHV-1 var (Fig.4).

Sequences obtained with the primer pair IA1/IA2 further discriminated two groups among the 32 analysed isolates: a first group of 17 isolates were identical to each other and $100 \%$ identical to the OsHV-1 reference sequence (data not shown). The second group constituted of 15 isolates presenting differences compared to the OsHV-1 reference isolate. For OsHV-1 $\mu V$ ar sequence, these differences corresponded to the variations of two nucleotides resulting from one deletion of "one Adenine (A)" at position 116 and one substitution of a "Cytosine (C) replaced by a Tyrosine (T)" at position 526 (Fig.5).

Thirty-two nucleotide sequences from the $C$ and the IA regions were obtained on 2008 isolates: 96\% homology between the OsHV-1 reference genotype and the OsHV-1 $\mu$ Var genotype were reported and 99\% homology between the OsHV-1 reference genotype and the genotype $\mu$ Var. $42.8 \%$ of 28 analysed batches from 2008 presented the genotype OsHV$1 \mu$ Var. In one of the 28 batches, batch 1, both OsHV-1 $\mu$ Var (isolates 1a, 1b) and OsHV-1 reference genotypes (isolate $1 \mathrm{c}$ ) were both detected (Table 1).

In order to determine if the $\mu$ Var genotype was retrospectively detected in archived samples, 44 isolates from oysters collected in 1995, 2003, 2004, 2005, 2006, or 2007 from France and the USA were analysed with PCR using C2/C6 and sequenced as described above. All sequences obtained were identical to each other and $100 \%$ identical to the OsHV-1 reference isolate.

As there was a greater polymorphism in the sequences of OsHV $\mu \mathrm{Var}$ using the $\mathrm{C} 2 / \mathrm{C} 6$ primers compared to IA1/IA2, the 44 isolates were only analysed using the C2/C6 primers.

\subsection{Analysis of amino acid sequences}

Sequence results using the primer pair IA1/IA2 showed presence of one synonymous substitution ( $\mathrm{T}$ to $\mathrm{C}$ ) in the coding region of ORF43. Alignment between the amino acids from the $\mathrm{C} 2 / \mathrm{C} 6$ fragment obtained with an isolate belonging to OsHV-1 $\mu$ Var group and the reference genotype. ORF 4 showed non-synonymous substitutions. The first substitution induced the modification of a GAU codon ( $D$ : aspartic acid) to an AAU codon (N: asparagine). The second substitution induced the modification of a GAA codon (E: glutamic 
acid) to an AAA codon ( $\mathrm{K}$ : lysine) (Fig. 6). These amino acid modifications were detected only in the OsHV-1 $\mu$ Var isolates.

\section{Discussion}

Massive mortality outbreaks affecting simultaneously all French oyster producing areas of juvenile Pacific oysters were reported in France in 2008 (Renault et al., 2009). Although causes of mortalities are currently being investigated, one of the most probable causes was identified as a herpes virus infection.

We described herein polymorphisms among some isolates collected during 2008 mortality outbreaks for both targeted virus genes, ORF4 (C region) and ORF43 (IA region). Indeed, 15 isolates presented variability in both $C$ and IA regions. Moreover, all these 15 isolates were identical to each other for both targeted ORF (ORF4 and ORF43). Namely, the 15 isolates showed two non-synonymous substitutions located in the coding region of the ORF 4. It is unknown if these substitutions determine changes in biological properties or protein conformation. On the contrary, the substitution observed in the coding area of the ORF43 is synonymous. The 15 isolates grouped all together on the basis of sequence data and were interpreted as a genomic variant of OsHV-1, termed OsHV-1 $\mu$ Var. A genomic variant has already been reported under the name OsHV-1 var (Arzul et al. 2001a). This variant was characterized by a large deletion around $2.8 \mathrm{kbp}$ in $\mathrm{C}$ region.

Genetic polymorphisms in vertebrate herpes viruses may be regarded as markers of geographical origins and/or distinct virus phenotypes (Grose et al., 2004; Bowden et al., 2006; Tornsello et al., 2010). Although the glycoprotein gB of HHV-7 (Human herpes virus 7) presented a certain degree of polymorphism depending on geographic origins (Franti et al., 1998), this polymorphism was not related to different virus phenotypes. On the contrary, polymorphism of gB in two other herpes viruses, HCMV (human cytomegalovirus) and HHV6 (human herpesvirus 6), induce amino acid changes which result in distinct virus phenotypes (Chou and Marousek, 1992). Based on the samples analysed herein, there were no geographical patterns in detection of OsHV-1 $\mu$ Var. Both genotypes (reference and $\mu \mathrm{Var}$ ) were detected in all the areas where samples have been collected in 2008, from the Mediterranean coast to Normandy. Moreover, a sample collected in China in 2002, presented the main deletion repeated for OsHV-1 1 Var in the $\mathrm{C}$ region. This isolate showed the main deletion consisting of 13 consecutive nucleic acids and all other polymorphisms reported for the $\mu$ Var genotype except two non-synonymous substitutions in ORF4 and $100 \%$ homology with reference genotype in ORF43 (data not shown).

Although no relationship was detected between geographical locations and virus genotypes, OsHV-1 reference genotype was mainly observed in samples collected in May and June 2008 and OsHV-1 $\mu$ Var genotype in July and August 2008 in France. Both OsHV-1 genotypes (reference and $\mu \mathrm{Var}$ ) were detected in association with mortality outbreaks reported in France in 2008. Recently experimental transmission challenges showed that OsHV-1 $\mu$ Var induced up to $100 \%$ mortality by intra-muscular inoculation in Pacific oyster spat (J-F. Pépin., personal communication.). These results raised the question about the virulence of OsHV-1 $\mu$ Var. However, more work is needed to fully investigate possible infectivity and virulence differences between the OsHV-1 reference genotype and the OsHV$1 \mu \mathrm{Var}$ genotype. Otherwise, the data collected in France in 2009 during mortality outbreaks on Pacific oyster spat displayed only the genotype OsHV-1 $\mu$ Var when OsHV-1 detection was associated with mortality events (OIE, 2009; Repamo, 2009). 
The original source of OsHV-1 $\mu$ Var remains unknown. Maybe unfavorable meteorological conditions of 2008, aquaculture practices, oysters imports from a continent other could have contributed to the emergence of the genotype OsHV-1 $\mu$ Var and numerous animal transfers between several French geographic regions could have contributed to dissemination of this genotype. A similar phenomenon was reported in koï carp infected with the koi herpes virus (KHV), Aoki.T. et al. (2007) hypothesized that intensive culture of common carp and koi carp, combined with large-scale movements of live fish, may have favored transmission of genetically deficient KHV strains of enhanced virulence.

For 15 isolates analysed, C2/C6 sequences present a deletion in a zone, presenting the characteristics of a microsatellite area. Microsatellites are short tandem repeats of 1 to 6 nucleotide motives and are highly polymorphic. As they are often highly variable, microsatellites are extensively used for the construction of linkage maps. This area is defined by 8 repeats of 3 nucleotides "CTA" in the OsHV-1 reference genotype (24 bp) and only 4 repeats in the OsHV-1 $\mu$ Var genotype either $12 \mathrm{bp}$, polymorphisms. That is the first report of a microsatellite polymorphism in OsHV-1. Microsatellites have already been reported in vertebrate herpes virus genomes and have been used to characterize different strains, especially in herpes cytomegalovirus (HCMC) (Davis et al., 1999; Walker et al., 2001; Picone et al., 2005) and more recently in HSV-1 (Deback et al., 2009).

Based on the polymorphisms observed in $\mathrm{C}$ region of the genome, namely a deletion in a particular microsatellite domain, we developed a PCR assay to distinguish both genotypes, OsHV-1 reference genotype and OsHV-1 $\mu$ Var genotype (data not shown).

Moreover, the detection of the two genotypes in some samples collected in 2008 let to suspect the presence of both genotypes in one individual. A study using the cloning technique has been carried out to investigate this aspect but has been inconclusive (data not shown).

Although the infection caused by OsHV-1 is not listed at present as a notifiable disease by the EU legislation (2006/88/EC, Annex IV) nor by the OIE (Aquatic Animal Health Code, 2009), a new EU regulation (Regulation 175/2010) was implemented in March 2010. This regulation lays down measures to be taken in the case of increased mortality in the species C. gigas in connection with the detection of OsHV-1 $\mu$ Var. When the presence of that virus has been detected, disease control measures should be implemented including the establishment of a containment area and the restriction to the movements out of the containment areas of $C$. gigas oysters.

The complete sequencing of OsHV-1 $\mu$ Var would be useful to explore polymorphisms in other regions of the virus. The Gp region, which encodes glycoproteins which is involved in recognition and attachment of the virus to the host cell membrane, may be subjected to many variations (Ericksson et al., 2004).

\section{Conclusion}

This article described the presence of a genotype of OsHV-1, termed OsHV-1 $\mu$ Var, detected in France in 2008 infecting $C$. gigas. The polymorphism reported in a microsatellite area in OsHV-1 $\mu$ Var may be suitable for many applications including strain differentiation and phylogeny studies (Goldstein et al., 1999).

Two Ostreid herpesvirus 1 genotypes were previously characterized: the OsHV-1 reference genotype and the OsHV-1var genotype. Our work revealed the emergence of a third genotype, OsHV-1 $\mu \mathrm{Var}$, associated with abnormal mortalities of $C$. gigas in France. This genotype was identified at least in $40 \%$ of collected spat batches in 2008 and in $100 \%$ of 
collected samples in 2009 (Repamo 2009). The detection of this third genotype since 2008 related to extensive mortality outbreaks among French Pacific oyster spat suggests an emerging disease situation. Epidemiology studies would be carried out additionally during future oyster mortality to confirm the detection of OsHV-1 $\mu$ Var.

\section{Acknowledgements}

The authors thank, Ifremer LGP team and Repamo team for donation of oyster samples and technical assistance; C. Friedman and K. S. Reece for providing not French OsHV-1 DNA samples tested. We also want to thank an anonymous referee for the helpful input and editorial comments in the review of this paper. We are very grateful to $\mathrm{C}$. Burge who edited the English.

\section{References}

Anonymous 2008. The World Animal Health Information Database Interface (WAHID), World Organisation for Animal Health (OIE). Available at: http://www.oie.int/wahis/public.php?page=event_summary\&reportid=7288. Accessed May 6, 2010.

Aoki, T., Hirono, I., Kurokawa, K., Fukuda, H., Nahary, R., Eldar, A., Davison, A.J., Waltzek T.B., Bercovier, H., Hedrick, R.P., 2007. Genome sequences of three koi herpesvirus isolates representing the expanding distribution of an emerging disease threatening koi and common carp worldwide. J. Virol. 81, 5058-5065.

Arzul, I., Renault, T., Lipart, C., Davison, A.J., 2001a. Evidence for interspecies transmission of oyster herpesvirus in marine bivalves. J. Gen. Virol. 82, 865-870.

Arzul, I., Nicolas, J.-L., Davison, A.J., Renault, T., 2001b. French scallops: a new host for Ostreid herpesvirus-1. Virology 290, 342-349.

Arzul, I., Renault, T., Thebault, A., Gérard, A., 2002. Detection of oyster herpesvirus DNA and proteins in asymptomatic Crassostrea gigas adults. Virus Research. 84, 151-160.

Bowden, R., Sakaoka, H., Ward, R., Donnelly, P., 2006. Patterns of Eurasian HSV-1 molecular diversity and inferences of human migrations. Infect. Genet. Evol. 6, 63-74.

Burge, C.A., Griffin, F.J., Friedman, C.S., 2006. Mortality and herpesvirus infections of the Pacific oyster Crassostrea gigas in Tomales Bay, California, USA. Dis. Aquat. Org. 72, 3143.

Burge, C.A., Judah, L.R., Conquest, L.L., Griffin, F.J., Cheney, D.P., Suhrbier, A., Vadopalas, B., Olin, P.G., Renault, T., Friedman, C.S., 2007. Summer seed: the influence of oyster stock, planting time, pathogens and environmental stressors. J. Shellfish Res. 26, 163-172.

Chou S, Marousek G I. Homology of the envelope glycoprotein B of human herpesvirus 6 and cytomegalovirus. Virology. 1992;191:523-528.

Davis, C.L., Field, D., Metzgar, D., Saiz, R., Morin, P.A., Smith, I.L., Spector, S.A., Wills, C., 1999. Numerous length polymorphisms at short tandem repeats in human cytomegalovirus. J. Virol. 73, 6265-6270.

Davison, A.J., Trus, B.L., Cheng, N., Steven, A.C., Watson, M.S., Cunningham, C., Le Deuff, R-M., Renault, T., 2005. A novel class of herpesvirus with bivalve hosts. J. Gen. Virol. 86, $41-53$

Davison, A.J., Eberle, R., Ehlers, B., Hayward, G.S., McGeoch, D.J., Minson, A.C., Pellet, P.E., Roizman, B., Studdert, M.J., Thiry, E., 2009. The order Herpesvirales. Archives of Virology 154, 171-177. 
Deback, C., Boutolleau, D., Depienne, C., Luyt, C.E., Bonnafous, P., Gautheret, A., Garrigue, I., Agut H., 2009. Utilization of Microsatellite Polymorphism for Differentiating Herpes Simplex Virus Type 1 Strains. J. Clin. Microbiol. 47, 533-540

Eriksson, K., Bellner, L., Gorander, S., Lowhagen, G-B., Tunback, P., Rydberg, K., Liljeqvist, J-A., 2004. CD4+ T-cell responses to herpes simplex virus type 2 (HSV-2) glycoprotein $G$ are type specific and differ in symptomatic and asymptomatic HSV-2-infected individuals. J. Gen. Virol. 85, 2139-2147.

Franti, M., Aubin, J.T., Poirel, L., Gautheret-Dejean, A., Candotti, D., Huraux, J.M., Agut, H., 1998. Definition and distribution analysis of glycoprotein $B$ gene alleles of human herpesvirus 7. J. Virol. 72, 8725-8730.

Friedman, C.S., Estes, R.M., Stokes, N.A., Burge, C.A., Hargove, J.S., Barber, B.J., Elston, R.A., Burreson, E.M., Reece, K.S., 2005. Herpes virus in juvenile Pacific oysters Crassostrea gigas from Tomales Bay, California, coincides with summer mortality episodes Dis. Aquat. Org. 63, 33-41.

Goldstein, D.B., Roemer, G.W., Smith, D.A., Reich, D.E., Bergman, A., Wayne R.K., 1999. The use of microsatellite variation to infer population structure and demographic history in a natural model system. Genetics. 151, 797-801.

Grose, C., Tyler, S., Peters G., Hiebert, J., Stephens, G-M., Ruyechan, W-T., Jackson, W., Storlie J., Tipples, G., 2004. Complete DNA sequence analyses of the first two VaricellaZoster virus Glycoprotein E (D150N) mutant viruses found in north America: Evolution of genotypes with an accelerated cell spread phenotype. J. Virol. 78, 6799-6807

Le Deuff, R.M. and Renault, T., 1999. Purification and partial genome characterization of a herpes-like virus infecting the Japanese oyster, Crassostrea gigas. J. Gen. Virol. 80, 13171322.

Lipart, C. and Renault, T., 2002. Herpes-like virus detection in infected Crassostrea gigas spat using DIG-labelled probes. J. Virol. Methods. 101, 1-10.

Moss, J.A., Burreson E.M., Cordes, J.F., Cungan, C.F., Brown, G.D., Wang, A., Wu, X., Reece, K.S., 2007. Pathogens in Crassostrea ariakensis and other Asian oyster species: implications for non-native oyster introduction in Chesapeake Bay. Dis. Aquat. Org. 77, 207233.

OIE, 2009. Suspected herpesvirus OsHV-1 frequently associated with Vibrio splendidus, France.

http://www.oie.int/wahis/reports/en_imm_0000008265_20090727_142743.pdf.

Accessed May 62010.

Pépin, J-F., Riou, A., Renault, T., 2008. Rapid and sensitive detection of ostreid herpesvirus 1 in oyster samples by realtime PCR. J. Virol. Methods. 149, 269-276.

Pernet, F., Barret, J., Marty, C., Moal, J., Le Gall, P., Boudry, P., 2010. Environmental anomalies, energetic reserves and fatty acid modifications in oysters coincide with an exceptional mortality event. Mar. Ecol. Prog. Ser. 401, 129-146

Picone, O., Ville, Y., Costa, J.M., Rouzioux, C. Leruez-Ville, M., 2005. Human cytomegalovirus (HCMV) short tandem repeats analysis in congenital infection. J. Clin. Virol. 32, 254-256.

Renault, T., Le Deuff, R.M., Cochennec, N., Maffart, P., 1994. Herpesvirus associated with mortalities among Pacific oyster, Crassostrea gigas, in France comparative study. Rev. Méd. Vét. 145, 735-742.

Renault, T. and Lipart, C., 1998. Diagnosis of herpes-like virus infections in oysters using molecular techniques. European Aquaculture Society Special Publication 26, 235-236.

Renault, T., Le Deuff, R-M., Chollet, B., Cochennec, N., Gerard, A., 2000a. Concomitant herpes-like virus infections in hatchery-reared larvae and nursery-cultured spat Crassostrea gigas and Ostrea edulis. Dis. Aquat. Org. 42, 173-183.

Renault, T., Le Deuff, R.M., Lipart. C., Delsert, C.,2000b. Development of a PCR procedure for the detection of a herpes-like virus infecting oysters in France. J. Virol. Methods. 88, 4150 . 
Renault T, Arzul I (2001) Herpes-like virus infections in hatchery-reared bivalve larvae in Europe: specific viral DNA detection by PCR. Journal of Fish Diseases 24: 161-167.

Renault T., Allain G., Arzul I., Chollet B., Cobret L., de Decker S., Faury N., Ferrand S., François C., Garcia C., Haffner P., Joly J. P., Michel J., Miossec L., Morga B., Nicolas J. L., Omnes E., Pépin J. F., Robert M., Saulnier D., Schikorski D., Segarra A., Tourbiez D. (2009). Summer mortality outbreaks of French Pacific oysters, Crassostrea gigas, in 2008: research and detection of pathogens. In: Diseases of Fish and Shellfish, 14th International Conference of the EAFP. Sept. 14-19. Prague, Czeck Republic, abstract O-112. p127.

Repamo, 2009. Bilan 2009 du réseau Repamo. Rapport interne Ifremer.45p. http://wwz.ifremer.fr/repamo/content/download/75792/522894/file/If_Rapport_REPAMO_200 9.pdf. Accessed July 222010.

Samain, J.F. and McCombie, H., 2008. Summer Mortality of Pacific oyster Crassostrea gigas, The Morest project. Eds Quae, Versailles, France.

Sauvage, C., Pepin, J.F., Lapegue, S., Boudry, P. and Renault, T. (2009) Ostreid herpes virus 1 infection in families of the Pacific oyster, Crassostrea gigas, during a summer mortality outbreak: differences in viral DNA detection and quantification using real-time PCR. Virus Res 142 (1-2), 181-187.

Tornesello, M., Biryahwaho, B., Downing, R., Hatzakis, A., Alessi, E., Cusini, M., Ruocco, V., Katongole-Mbidde, E., Loquercio, G., Buonaguro L., 2010. Human herpesvirus type 8 variants circulating in Europe, Africa and North America in classic, endemic and epidemic Kaposi's sarcoma lesions during pre-AIDS and AIDS era. Virology. 398, 280-289.

Walker, A., Petheram, S.J., Ballard, L., Murph, J.R., Demmler, G.J., Bale, J.F.Jr., 2001. Characterization of human cytomegalovirus strains by analysis of short tandem repeat polymorphisms. J. Clin. Microbiol. 39, 2219-26 
Tables

Table 1: Sample dates and origins of isolates from C. gigas spat or juvenile oyster collected in 2008. NCM: Natural capture Charente-Maritime. NA: natural capture Arcachon. HA: Hatchery A. HB: Hatchery B . HC: Hatchery C. HD: Hatchery D. CM: Charente-Maritime, LR: Languedoc Roussillon, N: Normandy, SB: South Brittany, NB: North Brittany, V: Vendée, A: Arcachon, l: unknown.

\begin{tabular}{|c|c|c|c|c|c|}
\hline Batch & $\mathrm{N}^{\circ}$ isolate & Hatchery & Origin & $\begin{array}{c}\text { Date of } \\
\text { sampling }\end{array}$ & Genotype \\
\hline \multirow{3}{*}{1} & $1 . \mathrm{a}$ & NCM & $\overline{\mathrm{CM}}$ & June 2008 & OsHV-1 $\mu \mathrm{Var}$ \\
\hline & 1.b & NCM & $\mathrm{CM}$ & June 2008 & OsHV-1 $\mu \mathrm{Var}$ \\
\hline & 1.c & NCM & $\mathrm{CM}$ & June 2008 & OsHV-1 ref. \\
\hline 2 & 2 & $\mathrm{HA}$ & LR & June 2008 & OsHV-1 ref. \\
\hline 3 & 3 & HD & LR & June 2008 & OsHV-1 ref. \\
\hline 4 & 4 & HD & $\overline{L R}$ & May 2008 & OsHV-1 ref. \\
\hline 5 & 5 & $\mathrm{HD}$ & LR & May 2008 & OsHV-1 ref. \\
\hline 6 & 6 & HD & LR & May 2008 & OsHV-1 ref. \\
\hline 7 & 7 & HD & LR & May 2008 & OsHV-1 ref. \\
\hline 8 & 8 & $\mathrm{HD}$ & LR & May 2008 & OsHV-1 ref. \\
\hline 9 & 9 & HB & LR & May 2008 & OsHV-1 ref. \\
\hline 10 & 10 & $\mathrm{HB}$ & LR & May 2008 & OsHV-1 ref. \\
\hline 11 & 11 & HA & LR & May 2008 & OsHV-1 ref. \\
\hline 12 & 12 & 1 & $\mathrm{~N}$ & June 2008 & OsHV-1 $\mu \mathrm{Var}$ \\
\hline 13 & 13 & $\mathrm{HD}$ & LR & July 2008 & OsHV-1 $\mu \mathrm{Var}$ \\
\hline 14 & 14 & NCM & $\mathrm{N}$ & July 2008 & OsHV-1 $\mu \mathrm{Var}$ \\
\hline 15 & 15 & $\mathrm{HB}$ & $\mathrm{CM}$ & July 2008 & OsHV-1 $\mu \mathrm{Var}$ \\
\hline 16 & 16 & HA & $\mathrm{CM}$ & June 2008 & OsHV-1 $\mu \mathrm{Var}$ \\
\hline \multirow{2}{*}{17} & 17.a & $\mathrm{HB}$ & $\mathrm{N}$ & July 2008 & OsHV-1 $\mu \mathrm{Var}$ \\
\hline & $17 . \mathrm{b}$ & HB & $\mathrm{N}$ & July 2008 & OsHV-1 $\mu \mathrm{Var}$ \\
\hline 18 & 18 & HA & SB & July 2008 & OsHV-1 $\mu \mathrm{Var}$ \\
\hline \multirow{2}{*}{19} & 19.a & $\mathrm{HA}$ & SB & July 2008 & OsHV-1 $\mu \mathrm{Var}$ \\
\hline & 19.b & $\mathrm{HA}$ & SB & July 2008 & OsHV-1 $\mu \mathrm{Var}$ \\
\hline 20 & 20 & HA & $\mathrm{SB}$ & July 2008 & OsHV-1 $\mu \mathrm{Var}$ \\
\hline 21 & 21 & NA & NB & July 2008 & OsHV-1 ref. \\
\hline 22 & 22 & $\mathrm{HB}$ & $\mathrm{CM}$ & June 2008 & OsHV-1 ref. \\
\hline 23 & 23 & $\mathrm{HD}$ & $\mathrm{CM}$ & May 2008 & OsHV-1 ref. \\
\hline 24 & 24 & HD & CM & May 2008 & OsHV-1 ref. \\
\hline 25 & 25 & $\mathrm{HD}$ & $\mathrm{CM}$ & May 2008 & OsHV-1 ref. \\
\hline 26 & 26 & $\mathrm{HB}$ & $\mathrm{CM}$ & August 2008 & OsHV-1 $\mu \mathrm{Var}$ \\
\hline 27 & 27 & $\mathrm{HC}$ & $\mathrm{V}$ & August 2008 & OsHV-1 ref. \\
\hline 28 & 28 & NA & $\mathrm{A}$ & August 2008 & OsHV-1 $\mu \mathrm{Var}$ \\
\hline
\end{tabular}


Table 2: Isolates of DNA extract of C. gigas spat or juvenile oyster collected in 1995, 2003, 2004, 2005, 2006 or 2007. HC: Hatchery C. HD: Hatchery D. CM: Charente-Maritime. N: Normandy. l: unknown.

\begin{tabular}{|c|c|c|c|c|c|}
\hline Batch & $\mathrm{N}^{\circ}$ isolate & Hatchery & Origin & $\begin{array}{c}\text { Date of } \\
\text { sampling }\end{array}$ & Genotype \\
\hline 29 & 29 & 1 & France & June 2007 & OsHV-1 ref. \\
\hline 30 & 30 & 1 & France & May 2007 & OsHV-1 ref. \\
\hline 31 & 31 & 1 & France & June 2007 & OsHV-1 ref. \\
\hline 32 & 32 & 1 & France & June 2007 & OsHV-1 ref. \\
\hline 33 & 33 & 1 & France & 2007 & OsHV-1 ref. \\
\hline \multirow{2}{*}{34} & 34.a & 1 & France & 2007 & OsHV-1 ref. \\
\hline & 34.b & 1 & France & 2007 & OsHV-1 ref. \\
\hline 35 & 35 & 1 & France & February 2007 & OsHV-1 ref. \\
\hline 36 & 36 & HD & $\mathrm{CM}$ & 2007 & OsHV-1 ref. \\
\hline 37 & 37 & $\mathrm{HC}$ & $\mathrm{N}$ & December 2006 & OsHV-1 ref. \\
\hline 38 & 38 & $\mathrm{HC}$ & $\mathrm{N}$ & October 2005 & OsHV-1 ref. \\
\hline 39 & 39 & $\mathrm{HC}$ & $\mathrm{N}$ & May 2006 & OsHV-1 ref. \\
\hline 40 & 40 & $\mathrm{HC}$ & $\mathrm{N}$ & May 2006 & OsHV-1 ref. \\
\hline 41 & 41 & $\mathrm{HC}$ & $\mathrm{N}$ & June 2006 & OsHV-1 ref. \\
\hline 42 & 42 & $\mathrm{HC}$ & $\mathrm{N}$ & July 2006 & OsHV-1 ref. \\
\hline 43 & 43 & $\mathrm{HC}$ & $\mathrm{N}$ & July 2006 & OsHV-1 ref. \\
\hline 44 & 44 & $\mathrm{HC}$ & $\mathrm{N}$ & July 2006 & OsHV-1 ref. \\
\hline 45 & 45 & 1 & $\mathrm{CM}$ & July 2006 & OsHV-1 ref. \\
\hline 46 & 46 & HD & $\mathrm{CM}$ & July 2006 & OsHV-1 ref. \\
\hline 47 & 47 & HD & $\mathrm{CM}$ & July 2006 & OsHV-1 ref. \\
\hline 48 & 48 & 1 & France & 2005 & OsHV-1 ref. \\
\hline 49 & 49 & 1 & France & 2005 & OsHV-1 ref. \\
\hline 50 & 50 & 1 & France & June 2005 & OsHV-1 ref. \\
\hline 51 & 51 & 1 & France & 2005 & OsHV-1 ref. \\
\hline 52 & 52 & 1 & France & 2005 & OsHV-1 ref. \\
\hline 53 & 53 & 1 & $\mathrm{CM}$ & 2004 & OsHV-1 ref. \\
\hline 54 & 54 & 1 & $\mathrm{CM}$ & May 2004 & OsHV-1 ref. \\
\hline 55 & 55 & 1 & $\mathrm{CM}$ & May 2004 & OsHV-1 ref. \\
\hline 56 & 56 & 1 & France & May 2004 & OsHV-1 ref. \\
\hline 57 & 57 & 1 & France & August 2003 & OsHV-1 ref. \\
\hline 58 & 58 & 1 & France & August 2003 & OsHV-1 ref. \\
\hline 59 & 59 & 1 & France & 2003 & OsHV-1 ref. \\
\hline 60 & 60 & 1 & France & July 2003 & OsHV-1 ref. \\
\hline 61 & 61 & 1 & France & August 2003 & OsHV-1 ref. \\
\hline 62 & 62 & 1 & France & August 2003 & OsHV-1 ref. \\
\hline 63 & 63 & 1 & France & 1995 & OsHV-1 ref. \\
\hline 64 & 64 & 1 & France & 1995 & OsHV-1 ref. \\
\hline 65 & 65 & 1 & France & 1995 & OsHV-1 ref. \\
\hline 66 & 66 & 1 & France & 1995 & OsHV-1 ref. \\
\hline 67 & 68 & 1 & USA California & July 2007 & OsHV-1 ref. \\
\hline 68 & 69 & 1 & USA California & August 2006 & OsHV-1 ref. \\
\hline 69 & 70 & 1 & USA & August 2006 & OsHV-1 ref. \\
\hline 70 & 71 & 1 & USA & July 2004 & OsHV-1 ref. \\
\hline 71 & 72 & 1 & USA Tomales bay & 2003 & OsHV-1 ref. \\
\hline
\end{tabular}

Table 3: Primer sequences used in PCR. 


\begin{tabular}{|c|l|c|c|}
\hline Primer name & \multicolumn{1}{|c|}{ Sequence 5’-3' } & $\operatorname{Tm}\left({ }^{\circ} \mathrm{C}\right)$ & Amplicon (bp) \\
\hline IA1 & CGC GGT TCA TAT CCA AAG TT & 59.9 & \multirow{2}{*}{607} \\
\hline IA2 & AAT CCC CAT GTT TCT TG CTG & 59.9 & \\
\hline C2 & CTC TTT ACC ATG AAG ATA CCC ACC & 60.1 & \multirow{2}{*}{709} \\
\hline C6 & GTG CAC GGC TTA CCA TTT TT & 60 & \\
\hline
\end{tabular}

Table 4: Restriction maps of the reference PCR products when the C2/C6 and IA1/IA2 primer sets were used. Fragment sizes were given in bp.

\begin{tabular}{|c|c|c|}
\multicolumn{1}{c|}{} & \multicolumn{1}{c}{$\begin{array}{c}\text { C2/C6 PCR } \\
\text { products }\end{array}$} & $\begin{array}{c}\text { IA1/IA2 PCR } \\
\text { products }\end{array}$ \\
\hline 5. TaqI & $/$ & $51 / 201 / 356$ \\
\hline MspI & $/$ & $163 / 360 / 85$ \\
\hline XhoI & $335 / 374$ & $/$ \\
\hline StyI & $258 / 451$ & $/$ \\
\hline
\end{tabular}


Figure 1: PCR products of isolates electrophoresed on a 1.5\% agarose gel using primer pairs (A) IA1/IA2; and (B) C2/C6. 1a-20: example of isolates P: positive control (OsHV-1 DNA). N: negative control (distilled water). : size of PCR products in bp. M: Small Marker (Eurogentec).

A

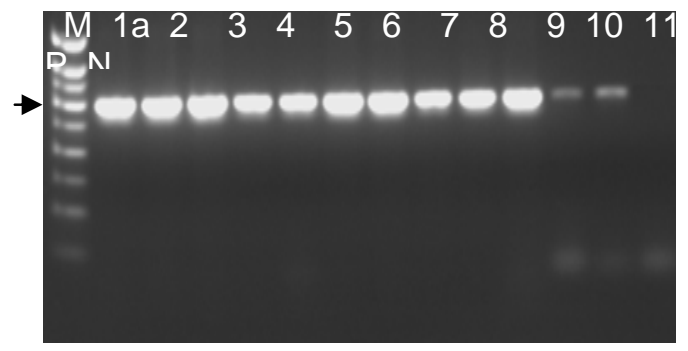

B

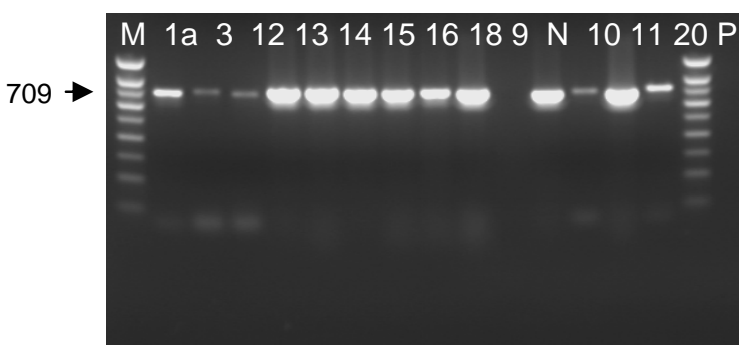

Figure 2: Restriction profiles obtained after digestion of PCR products IA1/IA2 by (A) TaqI and (B) Mspl. 1a-11: example of isolates. $\mathrm{P}$ : reference DNA. N: negative size of PCR products in bp. M: Small marker of size, (agarose gel 2\%).

A

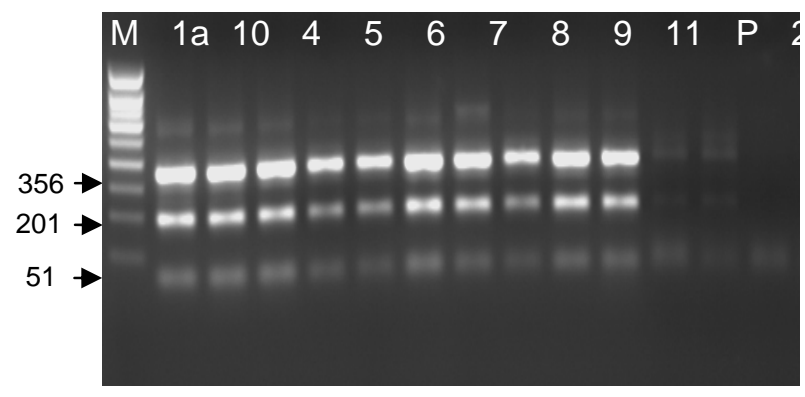

B

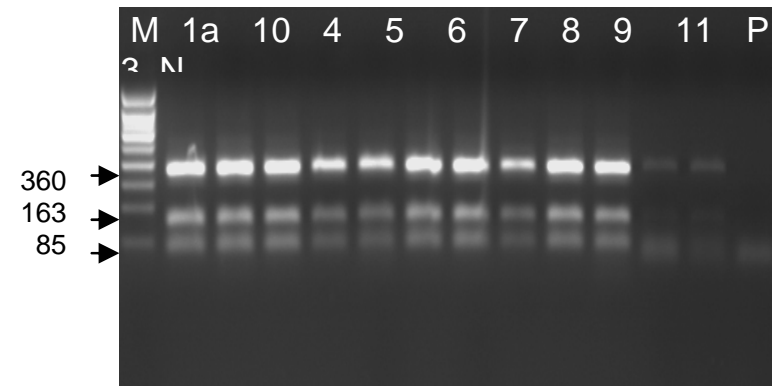

Figure 3: Restriction profiles obtained after digestion of PCR products C2/C6 by (A) Xhol and (B) Styl. All isolates have identical profiles, example of isolates: 2-12. C: reference DNA. N: negative control. : Size of PCR products in bp M: Small marker of size, (agarose gel 2\%). Higher size spots $\rightarrow$ from samples correspond to undigested PCR products due to excess of DNA.

A

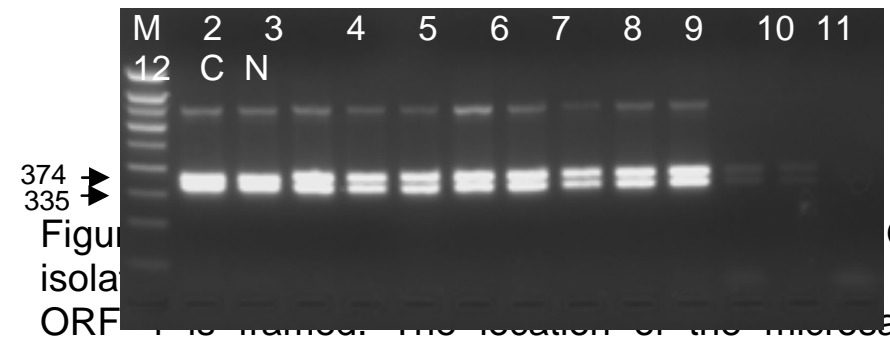

B

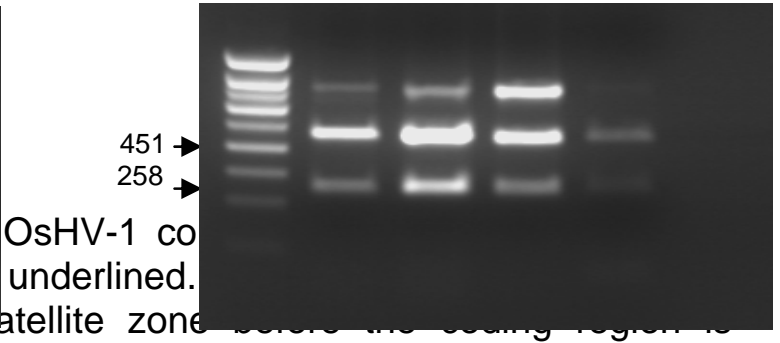

indicated. 
C2 Primer

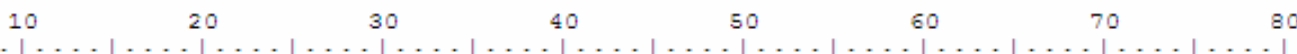

OsHV-1

OsHV-1 $\mathrm{NVar}$

OsHV-1

OsHV-1pVar

OsHV-1

OsHV-1pVar

OsHV-1

OsHV-1uVar

OsHV-1

OsHV-1pVar OsHV-1pVar

OsHV-1

OsHV-1uVar

OsHV-1

OsHV-1pVar

$<\quad$ Microsatellite zone CCСАCACACTCAATCTCGAGTATACCACAACTGCTAAATTAACAGCATCTACTACTACTACTACTACTACTACTGAAAAA

410

420

430

440

450

460

470

480

ATGFAGCCTT TCACAGAATTTTGCACCTTGACCAAAGCCATCACATCAGCCAGCAACGACTTTTTCATCAACCAGACGAG

ÖR̈́ $\dot{4} \ddot{>}$

500

510

520

530

540

550

560 作

570

580

590

600

610

620

630 640

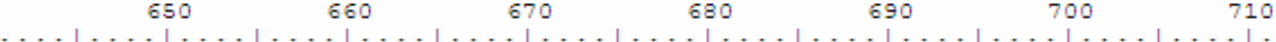

OsHV-1 TTTACCACTCTCATTGACGAATTGTTCACTGCCCACAAAGACCATTGTCAGAAAAATGGTAAGCCGTGCAC

C6 Primer 
Figure 5: IA1/IA2 sequence alignments between OsHV-1 consensus and an OsHV-1 $\mu$ Var isolate. The locations of primers IA2 and IA1 are underlined. The initiation codon (ATG) for ORF 43 is framed. 15 isolates with $99 \%$ homology are identical and displayed a type profile of OsHV-1 $\mu$ Var.

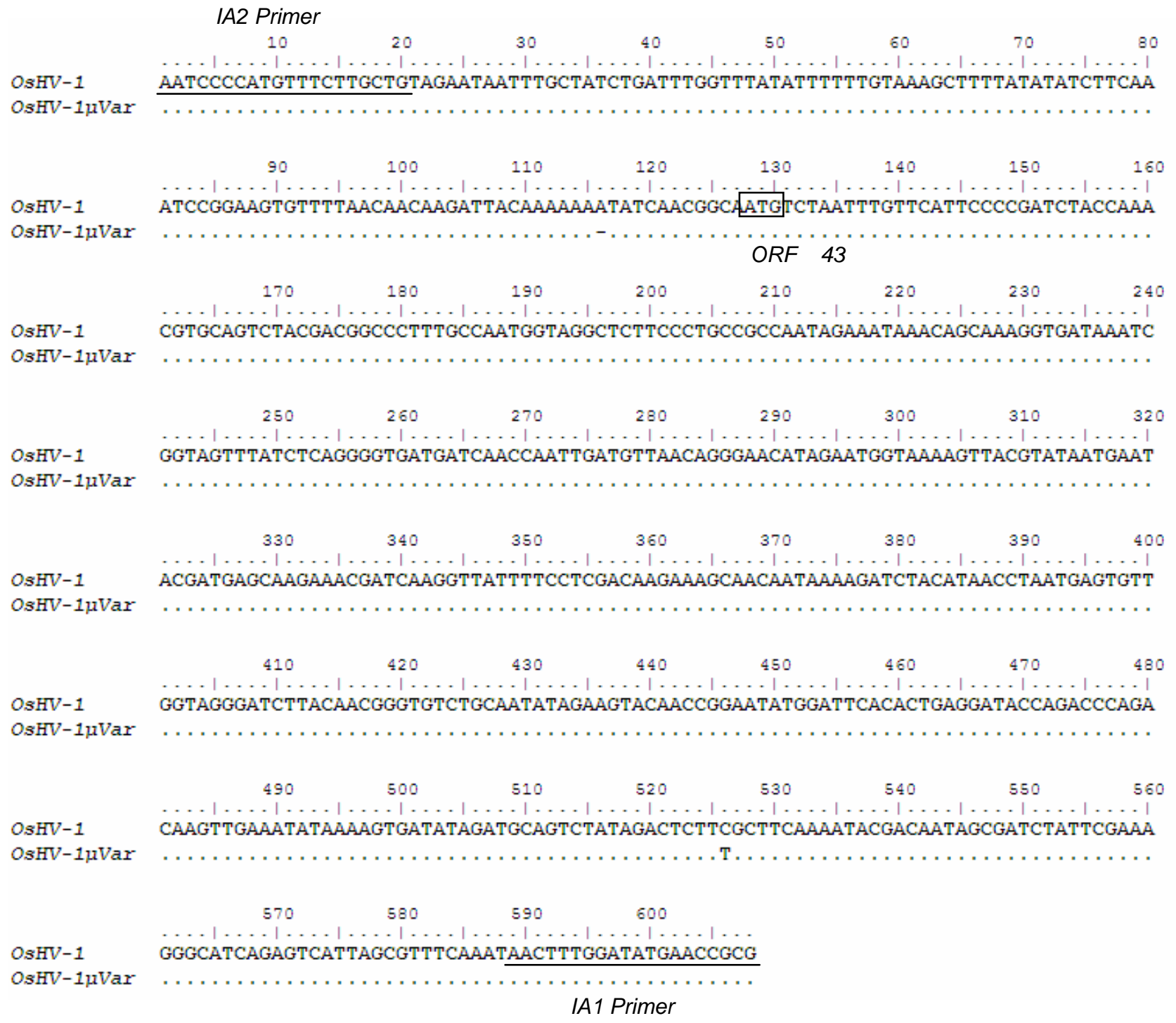

Figure 6: Alignment of amino acids sequences (ORF 4) between OsHV-1 reference and OsHV-1 $\mu$ Var.

0SHV-1 MQPFTEFCTLTKAITSASNDFFINQTRLTCDICKELVSFDCEDKVVASLAAVRSDIPIEVTERKDLNLLDLIQFFEKKIEFTTLIDELFTAHKDHCQ

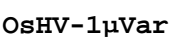
.N.K. 